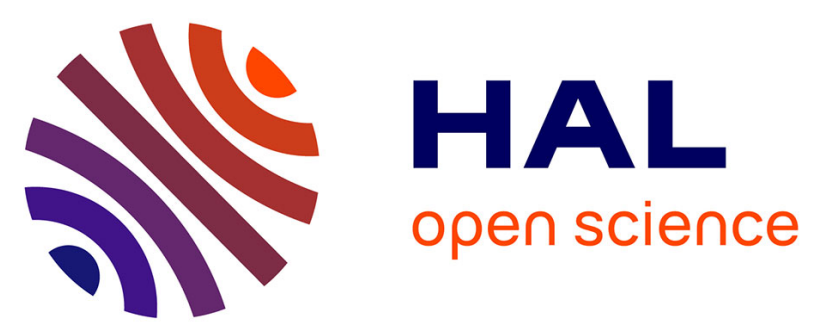

\title{
Do captive waterfowl alter their behaviour patterns during their flightless period of moult?
}

Steven J. Portugal, Rhian Isaac, Kate L. Quinton, S. James Reynolds

\section{To cite this version:}

Steven J. Portugal, Rhian Isaac, Kate L. Quinton, S. James Reynolds. Do captive waterfowl alter their behaviour patterns during their flightless period of moult?. Journal für Ornithologie = Journal of Ornithology, 2009, 151 (2), pp.443-448. 10.1007/s10336-009-0474-3 . hal-00568359

\section{HAL Id: hal-00568359 \\ https://hal.science/hal-00568359}

Submitted on 23 Feb 2011

HAL is a multi-disciplinary open access archive for the deposit and dissemination of scientific research documents, whether they are published or not. The documents may come from teaching and research institutions in France or abroad, or from public or private research centers.
L'archive ouverte pluridisciplinaire HAL, est destinée au dépôt et à la diffusion de documents scientifiques de niveau recherche, publiés ou non, émanant des établissements d'enseignement et de recherche français ou étrangers, des laboratoires publics ou privés. 
3 Do captive waterfowl alter their behaviour patterns during their

$4 \quad$ flightless period of moult?

6 Steven J. Portugal ${ }^{1 *}$, Rhian Isaac ${ }^{1}$, Kate L. Quinton ${ }^{1}$, and S. James Reynolds ${ }^{1}$

$8{ }^{1}$ The Centre for Ornithology, School of Biosciences, College of Life and Environmental

9 Sciences, The University of Birmingham, Edgbaston, Birmingham, B15 2TT, UK

11 * Correspondence: S. Portugal, The Centre for Ornithology, School of Biosciences,

12 College of Life and Environmental Sciences, The University of Birmingham, Edgbaston,

13 Birmingham, B15 2TT, UK.

14 E-mail address: S.Portugal.1@bham.ac.uk (S.J. Portugal).

17 Keywords: behaviour • captivity $\bullet$ common eider $\bullet$ dabbling duck $\bullet$ diving duck $\bullet$

18 garganey $\bullet$ moult

19

20 Short title: Captivity and moult behaviour in ducks 


\section{ABSTRACT}

29 Many different behavioural changes have been observed in wild waterfowl during the

30 flightless stage of wing moult with birds frequently becoming inactive and reducing time

31 spent foraging. Increased predation risk, elevated energetic demands of feather re-growth

32 and restriction of foraging opportunities are thought to underlie these changes. By

33 studying captive populations of both a dabbling and a diving duck species at the same

34 site, we determined whether captive birds would reflect the behavioural responses of wild

35 waterfowl to moult. The time-budgets of 42 common eiders, Somateria mollissima, (a

36 diving duck) and 18 garganeys, Anas querquedula, (a dabbling duck) were recorded

37 during wing moult (July-August) and non-moult (January) with behaviour recorded under

38 six categories. Despite captivity providing a low predation risk and constant access to

39 food, birds altered their behaviour during the flightless period of wing moult. Time

40 allocated to foraging and locomotion decreased significantly during moult compared to

41 non-moult periods, while resting time increased significantly. Moulting eiders underwent

42 a greater reduction in time spent foraging and in locomotion compared with garganeys,

43 which is likely to be in response to a higher energetic cost of foraging in eiders. It is

44 possible that increased resting in both diving and dabbling ducks reduces their likelihood

45 of detection by predators, while allowing them to remain vigilant. We demonstrate that

46 there is much potential for using captive animals in studies that can augment our

47 knowledge of behaviours of free-living conspecifics, the former being a hitherto under48 exploited resource. 


\section{INTRODUCTION}

53 Most waterfowl species undergo a complete moult of their flight feathers after

54 breeding, rendering them flightless for approximately 3 to 4 weeks (Hohman et al. 1992).

55 Many display marked changes in their behavioural time-budgets during this flightless

56 period (e.g. Adams et al. 2000; van de Wetering and Cooke 2000). For example, birds

57 will often become inactive and devote less time to foraging and maintenance such as

58 preening (e.g. canvasbacks, Aythya valisineria, Thompson 1992; harlequin ducks,

59 Histrionicus histrionicus, Adams et al. 2000). In addition, some species switch from

60 diurnal to nocturnal foraging (e.g. Kahlert et al. 1996), increase vigilance bouts (e.g.

61 Kahlert 2003) and/or reduce vocalisations to avoid detection by predators (e.g. Bailey

62 1981). An increase in predation risk as a result of being flightless, increased energy

63 demands through feather re-growth and restriction of foraging opportunities are

64 commonly cited reasons for these behavioural changes (Owen and Ogilvie 1979; Kahlert

65 2006).

66 Recent work by Portugal et al. (2007, 2009) on captive barnacle geese, Branta

67 leucopsis, provided the first evidence that captive waterfowl respond behaviourally to

68 wing moult in the same manner as free-living conspecifics by increasing time resting, and

69 decreasing time engaged in locomotion and foraging, despite the absence of predators and

70 despite access to ad libitum food in captivity. The captive geese showed other traits

71 characteristic of wild moulting waterfowl such as body mass loss (Portugal et al. 2007),

72 increases in metabolic rate (Portugal 2008) and changes in the leg and flight muscle 
73 morphology (Portugal et al. 2009, see also Douthwaite 1976; Guozhen and Hongfa 1986;

74 Fox et al. 1998 for studies on wild waterfowl). Therefore, it appears that by housing

75 geese in captive conditions with constant access to food and in the absence of predators,

76 they still respond behaviourally to moult in the same manner as moulting wild waterfowl.

77 This phenomenon in captive waterfowl has, however, only been studied in depth in

78 barnacle geese. Therefore, to gain a better perspective on whether similarities in the

79 behavioural responses to moult between wild and captive waterfowl are commonplace,

80 further species need to be examined. Working with captive moulting waterfowl presents

81 an opportunity to study moult behaviour and ecology in a far more detailed manner than

82 would be possible on wild moulting waterfowl, while also providing evidence of the

83 endogenous nature of behavioural responses. Here, we present preliminary evidence that

84 duck species also respond behaviourally to moult in a manner consistent with what would

85 be expected in moulting free-living waterfowl. We tested the hypotheses that during

86 moult the captive ducks would (1) decrease time dedicated to foraging and locomotion

87 and, (2) increase time spent resting. Furthermore, we predicted that (3) diving ducks

88 would reduce time spent foraging and in general locomotion to a greater extent during

89 moult than dabbling ducks.

90

91 METHODS

92

\section{Birds and maintenance}

94 Captive ducks were studied at the Wildfowl and Wetlands Trust (WWT)

95 headquarters at Slimbridge, Gloucestershire, UK $\left(51^{\circ} 43^{\prime} \mathrm{N} 3^{\circ} 37^{\prime} \mathrm{W}\right)$. Forty-two common

96 eiders, Somateria mollissima (hereafter referred to as 'eiders'), and 18 garganeys, Anas 
querquedula, were observed for a total of 39 days. Both species have had self-sustaining

98 populations at Slimbridge since $c .1980$ (R. Cromie, pers. comm.). Eiders (1.9-2.1 kg)

99 were selected as a representative diving duck species since they obtain their food

100 exclusively through diving (Guillemette et al. 2007). Garganeys (0.2-0.3 kg) were

101 selected as a representative dabbling duck species because they forage exclusively from

102 the surface of the water, by so-called 'up-ending' (Guillemain et al. 2004). Both species

103 had the largest number of individuals in a self-contained area at WWT where

104 observations of all individuals could be made at all times. Birds were not able to fly as

105 their flight feathers were cut annually or were pinioned. It was not possible to identify

106 individual ducks since they were not all ringed nor did they have distinguishing

107 morphological markings.

108 Birds were fed with a 1:1 diet (Lilico, Surrey, UK, Charnwood Milling Company

109 Ltd., Suffolk, UK) of mixed poultry corn (4\% fat, $12 \%$ protein and $71 \%$ carbohydrate)

110 and poultry grower's pellets (3\% fat, $16 \%$ protein and $61 \%$ carbohydrate) with the food

111 provided daily at approximately 10:00 hrs GMT. Food was thrown on the ground, in the

112 water and placed in feeding trays. Consequently, food was available ad libitum

113 throughout the day.

114 Eiders were housed in a large outdoor enclosure approximately an acre in size

115 comprising a lake with a maximum depth of approximately $3 \mathrm{~m}$, a number of small

116 islands, and areas of open grass and concrete. The eider's enclosure also included the

117 following other waterfowl species: Hawaiian geese (Branta sandvicensis), tufted ducks

118 (Aythya fuligula), greylag geese (Anser anser), mute swans (Cygnus olor), bar-headed

119 geese (Anser indicus) and barnacle geese. Garganeys were housed in an enclosure $15 \mathrm{~m}$

120 by $8 \mathrm{~m}$ with a shallow, reed-fringed lake, and open areas of grass and hedgerow. The 
121 garganeys enclosure also included the following other waterfowl species: African

122 pochard, Netta erythrophthalma, and white-headed duck, Oxyura leucocephala. For both

123 eiders and garganeys, all birds were adults. The male:female sex ratio was approximately

$124 \quad 1: 2$ and 2:1 for eiders and garganeys, respectively. None of the individuals had bred in the

125 year of the study.

126

127 Time-budgets

128 Time-budgets of ducks were recorded at two points during the annual cycle: $17^{\text {th }}$

129 July $-14^{\text {th }}$ August 2007 and $2^{\text {nd }}-12^{\text {th }}$ January 2008. In total, birds were observed for 130 approximately 36 hours during July - August, and 26 hours during January. Moult was

131 defined according to Ankney (1984), Bridge (2004) and Portugal et al. (2007). The July-

132 August period was considered the 'wing moult' sampling session (hereafter referred to as

133 'moult'), and the January period the 'non-wing moult' sampling session (hereafter

134 referred to as 'non-moult'). Birds were checked daily to assess moult stage and all birds

135 were in wing moult during the summer sampling period. Males and females moulted

136 synchronously. Behaviours were recorded in notebooks at two different times of day:

137 morning (summer and winter: 08:00 - 12:00 hrs GMT) and afternoon (summer: 13:00 -

138 18:00 hrs GMT; winter: 13:00 - 16:30 hrs GMT). Observations were made from vantage

139 points a short distance (c. $6 \mathrm{~m}$ ) away from the birds during periods when it was not

140 raining heavily. An individual bird was selected and observed for a total period of 5 min

141 with behaviours recorded every $15 \mathrm{~s}$. A focal bird was selected by choosing an individual

142 that had not knowingly just been sampled, and all birds were visible throughout the

143 duration of the sampling. If there was any disturbance (e.g. raptor flying over or members

144 of the public approaching birds at close range) during the observation period, data were 
145 discarded. So as to provide an approximate equal number of each sex, different sexes

146 were observed alternately (Mayhew 1987). Both species are sexually dimorphic during

147 moult and non-moult (Kear 2005). For both species, approximately 4325 min sampling

148 sessions were conducted during moult, and 3125 min sampling sessions during non-

149 moult. Overall, sampling sessions were comprised of a 50:50 ratio of afternoon and

150 morning sessions, and of male and female birds.

151 For both species, the following behaviours were recorded and pooled into six 152 general categories (after Goudie 1986; Austin 1987; Klaassen et al. 1994; Adams et al.

153 2000; Portugal et al. 2007): foraging (feeding and pausing during foraging bouts);

154 resting (loafing and sleeping); maintenance (preening, scratching, stretching and splash

155 bathing); locomotion (tail-wagging, walking, swimming, wing-flapping and scooting);

156 social (agonistic, antagonistic and courtship); and alert (head-raising and scanning the

157 immediate area). For eiders, diving was also added as a foraging category.

159 Statistical analysis

160 Following non-significant statistical testing between the sexes, data from the time161 budgets were pooled across the sexes for both species (eiders, ANOVA, $F_{(1,38)}=1.4, P=$ $162 \quad 0.17$; garganeys, ANOVA, $\left.F_{(1,38)}=1.7, P=0.1\right)$. For within-species comparisons, time 163 spent in each behavioural category from each sampling session was expressed as a 164 proportion of the observation period, which was arcsin square-root transformed to 165 normalize data. Two-way ANOVA revealed no difference in time-budgeting between 166 morning and afternoon observations within each sampling period for either eiders 167 (ANOVA, $\left.F_{(1,38)}=3.1, P=0.07\right)$ or garganeys (ANOVA, $F_{(1,38)}=3.6, P=0.08$ ) so 168 sessions were pooled. A one-way ANOVA (moult/non-moult as factors) with post-hoc 
169 Tukey HSD tests $(\alpha<0.01)$ was performed to test for differences in the mean proportion

170 of time dedicated to each category of behaviour between the moult and non-moult

171 periods. To determine how the time-budgets differed between species, a two-way

172 ANOVA with post-hoc Tukey's tests $(\alpha<0.01)$ was used, with each species and

173 sampling period as a category (i.e. eider moult, eider non-moult, garganey moult,

174 garganey non-moult). As the ducks were not individually identifiable, it was not possible

175 to guarantee independence of data. As such, all results are considered at the $\alpha=0.01$ level

176 of significance (sensu Grant and Grant 2002).

177

178

179 RESULTS

180

181 Within-species comparisons

182

183 When flightless, garganeys spent $41 \%$ of their time resting, a significant increase

184 compared with $12 \%$ of time during non-moult (Fig. 1 (a) and (b), respectively, ANOVA,

$\left.185 F_{(1,38)}=52.17, P<0.001\right)$. Thirteen per cent of time was spent foraging during wing

186 moult, a significant decrease compared with 39\% during non-moult (Fig. 1 (a) and (b),

187 respectively, ANOVA, $\left.F_{(1,38)}=51.72, P<0.001\right)$. Maintenance took significantly more

188 time (20\%) during moult than when not moulting (15\%; Fig. 1, (a) and (b), respectively,

189 ANOVA, $\left.F_{(1,38)}=4.32, P<0.01\right)$. Locomotion decreased significantly during moult to

$19023 \%$, compared to $32 \%$ during the non-moult period (Fig. 1, (a) and (b), respectively,

191 ANOVA, $\left.F_{(1,38)}=11.31, P<0.01\right)$. There were no significant changes in time spent in 
192 social or alert behaviour between moult and non-moult periods (Fig. 1 (a) and (b),

193 respectively).

194 Eiders during wing moult spent $55 \%$ of their time resting compared with $19 \%$

195 during non-moult, a significant increase (Fig. 1 (c) and (d), respectively, ANOVA, $F_{(1,38)}$

$196=38.23, P<0.001)$. Foraging decreased during wing moult, dropping significantly to $2 \%$

197 from $18 \%$ during non-moult (Fig. 1 (c) and (d), respectively, ANOVA, $F_{(1,38)}=57.24, P$

$198<0.001$ ). Maintenance behaviour increased significantly during wing moult (ANOVA,

$\left.199 F_{(1,38)}=53.96, P<0.001\right)$ from $10 \%$ (Fig. 1 (d)) in non-moult to $23 \%$ (Fig. 1 (c)) during

200 moult. During moult, eiders spent $18 \%$ of their time engaged in locomotory behaviour, a

201 significant decrease compared to $48 \%$ of their time when not moulting (Fig. 1, (c) and

202 (d), respectively, ANOVA, $\left.F_{(1,38)}=78.60, P<0.001\right)$. As in garganeys, there was no

203 significant change in time spent in social or alert behaviour between moult and non-moult 204 periods.

205

206 Between-species comparisons

207

208 During wing moult eiders underwent a greater reduction in combined time spent 209 engaged in locomotory and foraging activities, compared to that recorded in garganeys.

210 During non-moult, eiders spent $66 \%$ of time engaged in locomotion and foraging (Fig. 1

211 (d)) compared with $71 \%$ in garganeys (Fig. 1 (b)). In total, eiders spent $20 \%$ of time 212 engaged in foraging and locomotory activities during moult (Fig. 1 (c)) compared to $36 \%$

213 in garganeys (Fig. 1 (a)). ANOVA post-hoc Tukey's tests showed that garganeys were 214 more alert than eiders in both moult $(P<0.001)$ and non-moult $(P<0.01)$ periods, and 215 spent more time foraging $(P<0.001)$ than the eiders when not moulting. When not 
216 moulting, eiders spent significantly more time engaged in both locomotory $(P<0.001)$

217 and social $(P<0.05)$ activities than garganeys. During moult, eiders spent significantly

218 more time in maintenance $(P<0.001)$ and resting $(P<0.001)$ behaviours.

220 DISCUSSION

221

222 Captive ducks showed a marked change in behaviour between wing moult when they 223 were flightless and the period of non-moult. Both species showed a significant increase in

224 resting and maintenance behaviours while simultaneously reducing time spent foraging 225 and in locomotion. These behavioural changes occurred despite the captive birds never 226 having flown. Increased resting allows energy savings that can, in turn, be allocated to the 227 growth of new feathers. This would result in an increase in moult intensity and in a 228 potential shortening of the flightless period (Hohman et al. 1992). As birds have a lower 229 survival probability during periods of flightlessness than during volant ones (Pomeroy 230 1990), a shortening of the flightless period would be beneficial. In wild eiders, for 231 example, flightless birds are more likely to be predated by seals (Guillemette and Ouellet 232 2005). A recent study by Guillemette et al. (2007) noted that moulting eiders in the wild 233 do not reduce the duration or depth of dives during moult compared to non-moulting 234 periods of the annual cycle, although the number of dives was not reported. These 235 findings suggest, therefore, that it is not the increased cost of diving during moult per se 236 that is responsible for the reduction in foraging, but rather that diving is itself a costly 237 activity regardless of moult status, as has been demonstrated in eiders (Butler and Jones 238 1997; Hawkins et al. 2000). Piersma (1988) suggested that diving birds will also reduce 239 foraging during wing moult to minimise the risk of breaking newly growing flight 
240 feathers through the opening of the wings underwater during a dive. This, combined with

241 the energetic cost of diving, may explain why eiders do not increase foraging rate and

242 food intake during moult to compensate for the nutritional demands of feather

243 replacement.

244 No behavioural time-budget studies exist for garganeys or eiders. Studies

245 conducted on other moulting wild waterfowl have shown varying changes in time spent

246 resting and foraging during the flightless period. Redhead ducks, Aythya americana, and

247 red-crested pochards, Netta rufina, both of which are diving ducks, fed primarily at night

248 during wing moult (Bailey 1981; van Impe 1985), which may be related to predator

249 avoidance rather than to energetic savings as the colder water temperature at night would

250 increase thermoregulatory costs. Austin (1987) studied the response of diving ducks to

251 moult and reported a $10 \%$ increase in time spent resting during the flightless period in

252 lesser scaup, Aythya affinis, while mottled ducks, Anas fulvigula, spent only 9\% of their

253 time feeding during wing moult compared with $65 \%$ of their time before and after

254 (Paulus 1984). The same is true in black ducks, Anas rubripes, and canvasbacks

255 (Bowman 1987; Thompson 1992). The time spent foraging by mottled ducks (65\%)

256 reported by Paulus (1984) during non-moult periods is markedly higher than the $18 \%$ we

257 found in captive eiders. However, eiders were on a nutrient-rich diet, which may have

258 resulted in reduced foraging effort compared with free-living conspecifics.

259 There was a notable difference in the degree of change in behaviours between the

260 two species. Compared with the dabbling duck species, the diving duck demonstrated a

261 greater reduction in time spent in foraging and locomotory behaviours during wing moult

262 compared to non-moult. These foraging observations agree with those of Goudie and

263 Ankney (1976) who established that smaller species of ducks tended to spend 
264 proportionately more time feeding during wing moult than larger species. It is possible 265 that in our study, larger eiders (both in body mass and structural size; Kear 2005) were 266 able to deposit proportionately more fat prior to wing moult (Biebach 1996) than smaller 267 garganeys, enabling them to reduce foraging to a greater extent because of a greater 268 ability to mobilize endogenous fat stores during moult. The larger eiders will also have a 269 proportionately lower metabolic rate than the garganeys, so will need less food on a per $270 \mathrm{~kg}$ basis. It is unlikely that any species of waterfowl is able to cease foraging altogether 271 during moult (i.e. rely entirely on fat stores) unlike penguins, for example, which fast for 272 the duration of moult (e.g. Green et al. 2004). The present study is limited by our inability 273 to explore fully how feeding ecology influences behavioural responses to moult in ducks 274 as we compared only two species. Behavioural data from additional moulting waterfowl 275 species would be required to explore this in greater detail.

276 Ideally, future research on behavioral responses to moult in waterfowl would also 277 focus on the relationship between relative body fat stores prior to wing moult, and time 278 spent foraging and resting during moult, in both within and between-species comparisons.

279 To achieve this, birds would have to be individually marked and handled to quantify fat 280 reserves at the beginning and at the end of moult. This was not possible in the present 281 study as the WWT does not routinely handle birds and rings on birds are too small to be 282 read at distance or when birds are on water. Where circumstances allow, nasal saddles 283 and neck rings could be used to individually identify birds. An ability to identify 284 individual birds would significantly improve the study design and the statistical 285 approaches, enabling a repeated-measures statistical design to be employed. That said, 286 the present study was conducted as effectively as possible within the constraints of the 287 captive conditions at Slimbridge and it is difficult to foresee how we would obtain access 
288 to this number of birds without an organisation's cooperation. Nevertheless, we

289 demonstrate the latent value of such captive studies to unlock research potential.

290 In conclusion, captive ducks in our study still reduced time spent foraging during

291 the flightless period of wing moult. Eiders, a diving duck, reduced time spent foraging

292 and in locomotion to a greater extent than garganeys, a dabbling duck. This is likely to be

293 a response to the higher cost of foraging in the former. These behavioural changes

294 occurred despite the birds being flightless year-round in captivity, with constant access to

295 food and no predation. These findings suggest that increased resting during a potentially

296 vulnerable period of the bird's annual cycle is a highly endogenous and necessary

297 behavioural response to moult.

298

299 Zusammenfassung

300 Ändern Wasservögel in Gefangenschaft ihre Verhaltensmuster während ihrer

301 flugunfähigen Mauserperiode?

302

303 Bei wildlebenden Wasservögeln sind während des flugunfähigen Stadiums der

304 Flügelmauser viele unterschiedliche Verhaltensänderungen beobachtet worden - Vögel

305 wurden häufig inaktiv und reduzierten die Zeit der Nahrungsaufnahme. Es wird

306 angenommen, dass ein erhöhtes Prädationsrisiko, erhöhte Energieanforderungen durch

307 das Federwachstum und eine Einschränkung der Möglichkeiten zur Nahrungsaufnahme

308 diesen Veränderungen zugrunde liegen. Anhand zweier in Gefangenschaft gehaltener

309 Populationen einer Gründel- sowie einer Tauchente am selben Standort haben wir

310 untersucht, ob in Gefangenschaft gehaltene Vögel dieselben Verhaltensantworten auf die

311 Mauser wie wildlebende Wasservögel zeigen. Die Zeitbudgets von 42 Eiderenten 
312 Somateria mollissima (Tauchente) und 18 Knäkenten Anas querquedula (Gründelente)

313 wurden während der Flügelmauser (Juli-August) und im Januar ohne Mauser erfasst und

314 ihr Verhalten in sechs Kategorien eingeteilt. Obwohl Gefangenschaft ein niedriges

315 Prädationsrisiko und dauernden Zugang zu Futter bedeutet, änderten die Vögel ihr

316 Verhalten während der flugunfähigen Periode der Flügelmauser. Die Zeit, die für

317 Nahrungssuche und Fortbewegung aufgewendet wurde, nahm während der Mauser im

318 Vergleich zu Nicht-Mauser-Perioden signifikant ab, während die Ruhezeit signifikant

319 anstieg. Mausernde Eiderenten erfuhren eine stärkere Reduktion in der Zeit, die für die

320 Nahrungssuche und Fortbewegung aufgewendet wurde als Knäkenten, was

321 wahrscheinlich eine Reaktion auf die höheren Energiekosten der Nahrungssuche bei

322 Eiderenten ist. Es ist möglich, dass erhöhtes Ruhen bei Tauch- und Gründelenten die

323 Wahrscheinlichkeit der Entdeckung durch Fressfeinde reduziert, während es ihnen

324 erlaubt, wachsam zu bleiben. Wir zeigen, dass Potential besteht, in Gefangenschaft

325 gehaltene Tiere für Studien zu benutzen, die unser Wissen über Verhaltensweisen

326 wildlebender Artgenossen erweitern können. In Gefangenschaft gehaltene Tiere sind für

327 solche Studien bislang zu wenig verwendet worden.

328

\section{Acknowledgments}

330 We are very grateful to the staff, particularly Dr Ruth Cromie, and keepers at the WWT, 331 Slimbridge, for allowing the study to be conducted, and to Louise Barrett, Diego Gill, Jon

332 Green and Susannah Thorpe for reading earlier drafts of the manuscript. Thanks to Lewis

333 Halsey, Peter Shaw and Craig White for statistical advice. We are grateful also to three

334 anonymous reviewers for their comments on the manuscript. Funding for the work was

335 provided by the School of Biosciences at the University of Birmingham. 


\section{References}

338 Adams, P. A., Roberson, G. J. and Jones, I. L. (2000) Time-activity budgets of harlequin

339 ducks molting in the Gannet Islands, Labrador. Condor 102: 703-708.

340 Ankney, C. D. (1984) Nutrient reserve dynamics of breeding and moulting Brant. Auk

$341 \quad 101: 361-370$.

342 Austin, J. E. (1987) Activities of postbreeding lesser scaup in southwestern Manitoba.

343 Wilson Bulletin 99: 448-456.

344 Bailey, R. O. (1981) The postbreeding ecology of the redhead duck (Anas americana) on

345 Long Island Bay, Lake Winnipegosis, Manitoba. PhD Dissertation, McGill University,

346 Montreal, PQ, Canada.

347 Biebach, H. (1996) Energetics of winter and migratory fattening. In: Avian energetics and

348 nutritional ecology (Ed. by C. Carey), pp. 280-323. London: Chapman and Hall.

349 Bowman, T. D. (1987) Ecology of male Black Ducks molting in Labrador. MSc thesis,

350 University of Maine, Orono, ME, USA.

351 Bridge, E. S. (2004) The effects of intense wing moult on diving in alcids and potential

352 influence on the evolution of molt patterns. J. Exp. Biol 207: 3003-3014.

353 Butler, P. J. and Jones, D. R. (1997) Physiology of diving birds and mammals.

354 Physiology Reviews 77: 837-899.

355 Douthwaite, R. J. (1976) Weight changes and wing moult in the Red-billed Teal.

356 Waterfowl 27: 123-127.

357 Fox, A. D., Kahlert, J., Walsh, A. J., Stroud, D. A., Mitchell, C., Kristiansen, J. N. and

358 Hansen, E. B. (1998) Patterns of body mass change during moult in three different goose

359 populations. Wildfowl 49: 45-56. 
360 Goudie, R. I. (1986) Behaviour of harlequin ducks and three species of scoters wintering 361 in the Queen Charlotte Islands, British Columbia. In: Behaviour and ecology of sea ducks 362 (Ed. by R. I. Goudie, M. R. Peterson and G. J. Robertson), pp. 6-13. Ottawa: Canadian 363 Wildl. Serv. Occ. Pap. No. 100.

364 Goudie, R. I. and Ankney, C. D. (1976) Body size, activity budgets, and diets of sea

365 ducks wintering in Newfoundland. Ecology 67: 1475-1482.

366 Green, J. A., Butler, P. J., Woakes, A. J. and Boyd, I. L. (2004) Energetics of the moult 367 fast in female macaroni penguins (Eudyptes chrysolophus). - J. Avian Biol., 35, 153-161.

368 Grant, P. R. and Grant, B. R. (2002) Unpredictable evolution in a 30-year study of 369 Darwin's finches. Science 296: 707-711.

370 Guillemain, M., Fritz, H., Klassen, M., Johnson, A. R. and Hafner, H. (2004) Fuelling

371 rates of garganey (Anas querquedula) staging in the Carmague, southern France, during 372 spring migration. J. Ornithol 145: 152-158.

373 Guillemette, M. and Ouellet, J.-F. (2005) Temporary flightlessness as a potential cost of 374 reproduction in pre-laying common eiders. Ibis 147: 301-306.

375 Guillemette, M., Pelletier, D., Grandbois, J.-M. and Butler, P. J. (2007) Flightlessness

376 and the energetic cost of wing moult in a large sea duck. Ecology 88: 2936-2945.

377 Guozhen, Q. and Hongfa, X. (1986) Molt and resting metabolic rate in the common teal 378 Anas crecca and the shoveler Anas clypeata. Acta Zoologica Sinica 32: 73-84.

379 Hawkins, P. A. J., Butler, P. J., Woakes, A. J. and Speakman, J. R. (2000)

380 Estimation of the rate of oxygen consumption of the common eider duck (Somateria 381 mollissima), with some measurements of heart rate during voluntary dives. J. Exp. Biol $382 \quad 203: 2819-2832$. 
383 Hohman, W. L., Ankney, C. D. and Gordon, D. H. (1992) Ecology and management of

384 postbreeding waterfowl. In: Ecology and management of breeding waterfowl (Ed. by B.

385 D. J. Batt, A. D. Afton, M. G. Anderson, C. D. Ankney, D. H. Johnson, J. A. Kadlec and

386 G. L. Krapu), pp. 128-189. University of Minnesota, Minneapolis, MN, USA.

387 Kahlert, J., Fox, A. D. and Ettrup, H. (1996) Nocturnal feeding in moulting Greylag

388 Geese Anser anser - an anti predator response? Ardea 84: 15-22.

389 Kahlert, J. (2003) The constraints on habitat use in wing-moulting greylag geese, Anser

390 anser, caused by anti-predator displacements. Ibis 145: E45-E52.

391 Kahlert, J. (2006) Effects of feeding patterns on body mass loss in moulting Greylag

392 Geese Anser anser. Bird Study 53: 20-31.

393 Kear, J. (2005) Ducks, geese and swans. New York: Oxford University Press.

394 Klaassen, M., Habekkotte, B., Schinkelshoek, E. S. and van Tienin, P. (1994) Influence

395 of growth rate retardation on time budgets and energetics of Arctic tern, Sterna

396 paradisaea, and common tern, Sterna hirundo, chicks. Ibis 136: 197-204.

397 Mayhew, P. W. (1987) Vigilance levels in European Wigeon, Anas penelope - sexual

398 differences. Wildfowl 38: 77-81.

399 Owen, M. and Ogilvie, M. A. (1979) The molt and weights of barnacle geese in 400 Spitsbergen. Condor 81: 42-52.

401 Paulus, S. L. (1984) Behavioural ecology of Mottled Ducks in Louisiana. PhD 402 Dissertation, Auburn University, Auburn, LA, USA.

403 Piersma, T. (1988) Breast muscle atrophy and constraints on foraging during the 404 flightless period of wing moulting great crested grebes. Ardea. 76: 96-106.

405 Pomeroy, D. (1990) Why fly? The possible benefits of lower mortality. Biol. J. Linn. Soc 406 40: 53-65. 
408 resting metabolism in captive barnacle geese (Branta leucopsis). J. Exp Biol 210: 13914091397.

410 Portugal, S. J. (2008) Ecophysiological aspects of the annual cycle of barnacle geese,

411 Branta leucopsis. PhD thesis, University of Birmingham, Birmingham, UK.

412 Portugal, S. J., Thorpe, S. K. S., Green, J. A., Myatt, J. P. and Butler, P. J. (2009) Testing

413 the use/disuse hypothesis: pectoral and leg muscle changes in captive barnacle geese 414 Branta leucopsis during wing moult. J. Exp. Biol In press.

415 Thompson, J. E. (1992) The nutritional ecology of molting male Canvasbacks (Aythya 416 valisineria) in central-Alberta. MSc thesis, University of Missouri, Columbia, MO, USA.

417 van Impe, J. (1985) Mue des remiges chez la nette a huppe rousse Netta rufina en 418 espagne du nord. Alauda 53: 2-10.

419 van de Wetering, D. and Cooke, F. (2000) Body weight and feather growth of male 420 Barrow's goldeneye during wing moult. Condor 102: 228-231.

\section{$426 \quad$ Figure legends}

428 Figure 1. Time activity budgets of 18 captive garganeys ((a) and (b)), and 42 captive 429 common eiders ((c) and (d)) between moult and non-moult periods, respectively. 
MOULT

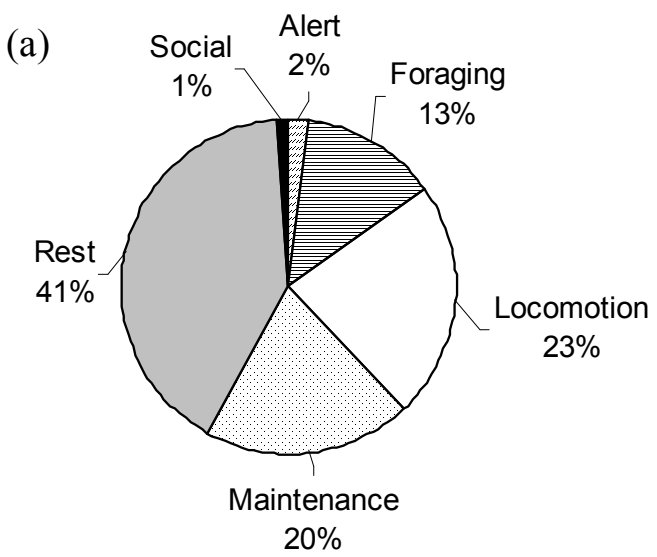

(c)

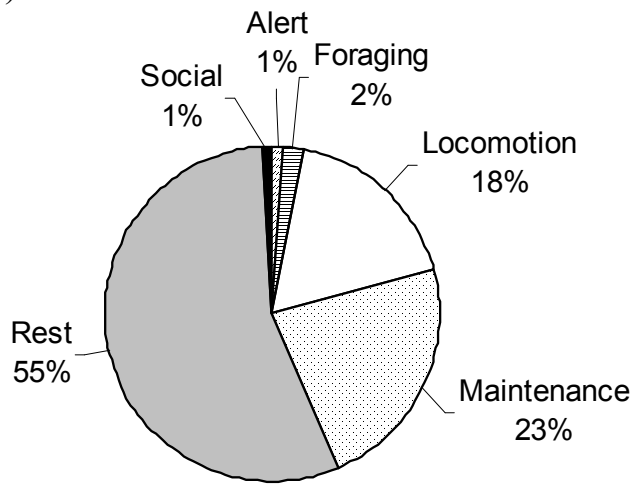

NON-MOULT

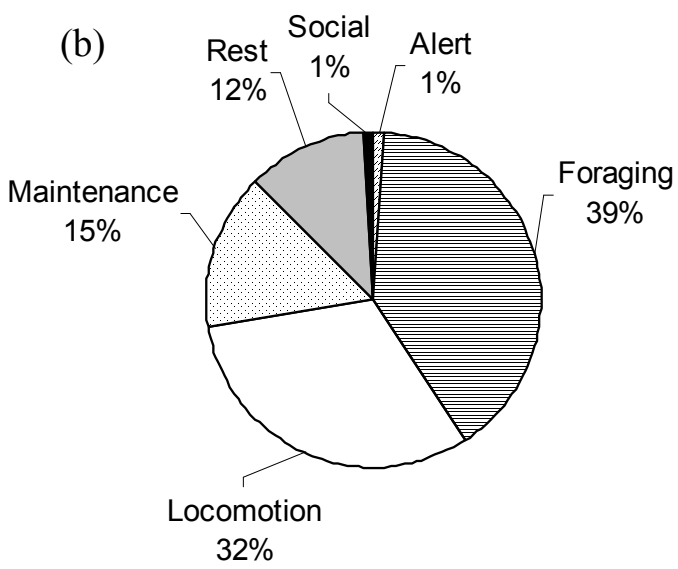

(d)

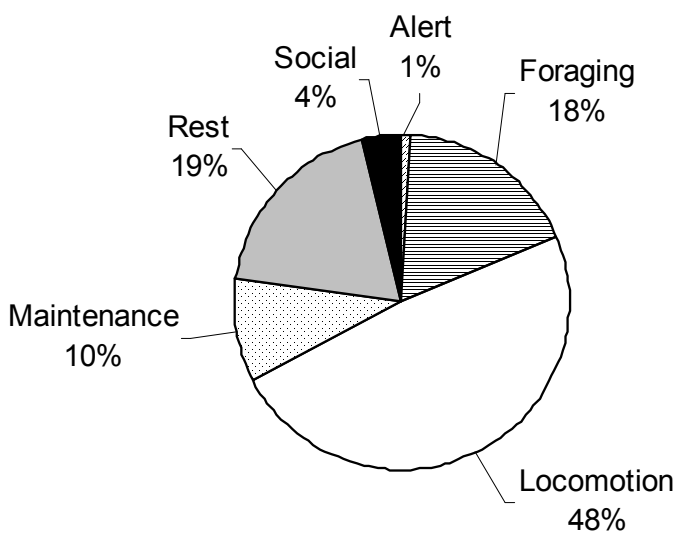

GARGANEY

EIDER

Fig. 1 